\title{
CREATIVE FINANCING BY MULTINATIONALS
}

\author{
Jeff Madura \\ College of Business \\ University of Central Florida \\ Orlando, Florida \\ Robert Boothe \\ Fogelman College of Business \\ Memphis State University \\ Memphis, Tennessee
}

Multinational corporations (MNCs) are well aware of the potential rewards and existing risks when operating in foreign environments. While MNCs commonly consider the possibility of lower labor or land costs when producing goods overseas, they often neglect the potential reduction in costs due to financing opportunities available in other countries. Relatively low interest rates in some foreign countries will allow for low financing costs for subsidiaries located in these countries. Yet, these low foreign interest rates can also support other subsidiaries as well as the parent in other countries where interest rates are relatively high. The following discussion focuses on how MNCs can finance much of their global operations with funds from countries where interest rates are low. If conducted correctly, foreign financing can easily save a MNC millions of dollars each year without exposure to exchange rate risk.

\section{The Financing Decision}

Consider a hypothetical U.S. based MNC called GLOBAL Inc., that has foreign production and revenue source subsidiaries in a country that notoriously has high interest rates (called "HINT") and in a second country with notoriously low interest rates (called "LINT"). GLOBAL Inc. would likely obtain some financing in LINT for its subsidiaries based there. Revenues generated by these subsidiaries can be used to pay back the low interest rate loans. Yet, GLOBAL Inc. may finance the remainder of its operations with funds from the U.S. (its parent's home country), and from HINT, even though interest rates are higher in these countries. The obvious reason for not more fully capitalizing on the low-interest rates in LINT is that such loans would have to be paid back in LINT's home currency (from here on referred to as the LINT franc). If the LINT franc substantially appreciated against the revenue source currencies over the loan life, the effective (exchange rate adjusted) financing rate could be quite high. 
MNCs are well aware of techniques such as a forward hedge to cover against exchange rate fluctuations. They could, for example, borrow LINT francs at the low interest rate, convert them to the currency needed, and simultaneously negotiate a forward purchase of the LINT franc for the time at which the loan is to be repaid. Yet, under conditions of interest rate parity, the forward rate on the franc would contain a premium large enough to offset the interest rate differential. If so, GLOBAL Inc. would not be reducing its financing costs. Because of this offsetting effect from forward hedging, MNCs that wish to avoid the exchange rate risk may give in and simply decide to finance in whatever currency can be matched by future inflows (balance sheet hedging). GLOBAL Inc., for example, may simply finance HINT's operations from local banks in HINT. Even though the interest rate is higher in HINT, future inflows to subsidiaries located there will most likely be denominated in HINT's currency and can therefore be used to repay the loans without exposure to exchange rate risk. While this strategy may appear sensible on the surface, it reflects neglect of several possible alternative approaches that could substantially reduce the MNC's overall financing cost. These alternative approaches are discussed below.

\section{Techniques to Use Foreign Financing Without Increasing Exchange Rate Exposure}

There are a variety of techniques available to the MNC for obtaining funds from the low interest country (LINT in our example) and covering the exchange rate risk. The appropriate technique or techniques that a MNC should use depend on the characteristics of the MNC. All techniques reflect an effort to obtain future cash inflows in LINT francs so that low interest rate loans previously obtained from LINT could be repaid without worry about exchange rate fluctuations. The techniques can generally be classified into one of four multinational corporate policies:

- Invoicing Policy

- Transfer Pricing Policy

- Dividend Remittance Policy

- Strategic Planning Policy

A discussion of how each policy can be implemented to achieve a reduction in financing costs follows.

\section{Invoicing Policy}

Perhaps the most common invoicing policy for the problem at hand is for the U.S. parent and subsidiaries in HINT to invoice some of their products in LINT francs. This would generate cash flows in LINT francs, which could be used to repay loans from LINT. If, for example, some foreign customers 
commonly have net receivables in LINT francs, they may desire to pay for their imports from GLOBAL Inc. in francs. For the same reason, the U.S. parent of GLOBAL should determine whether any U.S. companies it sells products to would prefer to make payment in LINT francs. Similarly, subsidiaries located in HINT should replicate this effort for their sales.

MNCs that consider the possibilities above exhibit the imagination necessary to obtain low cost financing without becoming exposed to exchange rate risk. Yet, the invoicing strategy identified above may only allow for a portion of the overall MNC's financing to be obtained at low interest rates. If GLOBAL Inc. could create more sources of LINT franc revenues, it could afford to obtain more financing in LINT francs and cover the future interest payments on this financing with these additional sources. For example, consider a subsidiary of GLOBAL based in LINT that periodically purchases dollar-denominated supplies from a U.S. supplier. These subsidiaries in LINT could ask their U.S. parent to make payment to the U.S. suppliers for them. In exchange for this favor, the subsidiaries in LINT could use their francs that they normally would have converted to dollars to pay for exports from the U.S. supplies to instead repay franc-denominated loans initially drawn by the U.S. parent. In this way, additional financing could be obtained at low interest rates and an additional source of LINT franc revenues world be created to cover future interest payments on previous loans.

The invoicing possibilities are endless. Subsidiaries in LINT may even find some local businesses that prefer payment in a currency other than the franc (perhaps to cover their own net payables positions). If so, the subsidiaries in LINT, when purchasing local goods, could arrange for the U.S. parent or subsidiaries in HINT to use their respective currencies to pay for these goods. In return, the subsidiaries in LINT could use their cash inflows to repay francdenominated loans drawn by HINT subsidiaries or the U.S. parent.

\section{Transfer Pricing Policy}

Beyond invoicing strategies, GLOBAL Inc. could also adjust its transfer pricing policies to allow for additional financing in LINT francs. For example, assume that subsidiaries in LINT and HINT trade with each other. If LINT subsidiaries were charged low prices for imported supplies, this would allow them to retain more of their funds to repay franc-denominated loans drawn by any part of GLOBAL Inc. Any supplies or managerial services provided by the U.S. parent to LINT subsidiaries could also be handled in the same manner. All transfer pricing decisions should be made with consideration of any constraints that may be imposed by the host government.

\section{Dividend Remittance Policy}

The dividend remittance policy by GLOBAL Inc. can also be tailored to insulate against exchange rate risk when financing in LINT francs. For example, the U.S. parent could have borrowed francs at the low interest rate and converted these francs into dollars for use in the U.S. It could then in- 
struct the subsidiaries in LINT to use a portion of their earnings in francs to make interest payments on franc loans drawn by the parent rather than send dividends to the parent. This not only locks in the low financing cost for GLOBAL Inc. but also avoids transaction costs of converting francs into dollars, and can even avoid a withholding tax that may have been imposed by the LINT government on dividends remitted back to the parent.

\section{Strategic Planning Policy}

Even a firm's strategic planning on where to establish future subsidiaries can reduce financing costs. Consider a situation where GLOBAL Inc. plans to establish a research and development subsidiary. Because the function of such a subsidiary is not to generate revenues but to create products that may someday be marketed by other subsidiaries, it will operate at a loss. The strategic planning division should consider this information as it decides where to establish such a subsidiary. If the subsidiary was built in LINT, it would absorb LINT francs from GLOBAL Inc. in order to cover operating costs. This would use up a portion of the franc revenues that could be used to cover interest payments on existing loans, and therefore reduce GLOBAL's ability to match future cash inflows with future liabilities in LINT francs, but should be located elsewhere so that it absorbs some other currency to cover operating expenses.

Now consider a second strategic plan of GLOBAL Inc. to establish a subsidiary that will act as a distribution center, receiving finished goods from other subsidiaries and sending them to importers from various countries. Such a subsidiary could be GLOBAL's cash cow, since the cost of producing the products could be largely incurred by the subsidiaries that produced the goods. LINT would be the ideal location for such a cash cow subsidiary, since the products received by the distribution subsidiary and exported to various markets could be invoiced in francs, thereby serving as a source of LINT franc revenues. It is possible that the location of LINT relative to the markets where the products are to be sold is not appropriate for a distribution subsidiary (as export transportation costs may be excessive). In this case, the subsidiary could be set up in another country, but still invoice much of the exports in LINT francs. The discussion illustrates how proper strategic planning would be able to generate periodic cash inflows over the long run of whatever currency the MNC has used to finance its assets.

\section{Operationalizing the Approach}

Some MNCs are using the creative financing techniques described here. For example, Honeywell Inc. has been known to borrow foreign currencies in which it has future receivables, so that it can cover repayment on such loans. Other MNCs have from time to time used subsidiary-generated earnings to pay coupon payments on bonds denominated in that currency. Yet, it is unusual for MNCs to conduct a complete analysis on its sources of financing, with the intention of reducing the firm's cost of capital. MNCs typically devote 
more resources to enhancing revenues or reducing production costs, but rarely evaluate their financial liability position. A dollar saved due to lower financing costs is just as valuable as a dollar save due to reduced production cost. Furthermore, it is more valuable than an extra dollar earned from increasing revenue, since additional revenues contribute to earnings by only a fraction (the profit margin) of their increase.

To operationalize the approach prescribed here, an $\mathrm{MNC}$ needs to first identify sources of low cost funds. Even as interest rates do change over time, some countries typically maintain lower interest rates than others. For example, interest rates in Japan, Switzerland, and West Germany are commonly lower than in other countries. In some cases, it is not necessary to borrow specifically from banks in these countries since the currencies involved here are available in the Eurocurrency market. Our hypothetical example specified only the LINT franc as a low cost source of funds. In reality, an MNC with subsidiaries in any countries where interest rates are low may have several alternative sources. This allows for more flexibility in operationalizing the policies recommended to obtain low cost financing. Ideally, the MNC would attempt to generate much of its aggregate revenues in the currencies that exhibit low interest rates. Its invoicing, transfer pricing, dividend remittance and strategic planning policies would be designed to insulate against the exchange rate risk that results.from financing in one or more low-interest rate currencies. This recommendation is not limited to short-term or even medium-term loans. From a long-term financing perspective, the MNC could even denominate its bonds in a currency that exhibits a low interest rate and enact policies that force enough periodic net cash inflows in that currency to cover future coupon payments.

The amount of financing that can be done in low cost sources of funds without incurring exchange rate risk is dependent on the volume of net cash inflows of these low interest rate currencies that can be generated by the MNC. The major limitation of MNCs in generating sufficient cash inflows in these currencies is lack of imagination in modifying their invoicing, transfer pricing, dividend remittance, and strategic planning policies. Some critics may mistakenly take the term imagination to infer risky speculative strategies. To the contrary, imagination in the context of multinational financing can achieve a lower cost of financing and simultaneously hedge against exchange rate risk.

Many large MNCs have the equivalent of $\$ 1$ billion or more in long-term debt alone. If they could reduce their average cost of financing by just one percentage point, annual interest payments on $\$ 1$ billion would be reduced by $\$ 10$ million, and annual pretax profits would rise by $\$ 10$ million. In reality, a MNC may not be able to transform all of its liabilities into a low interest rate currency unless it was willing to accept some unhedged exposure in that currency. Yet, it may easily be able to transform 10 percent or more of its local liabilities to a low interest rate currency, and adequately cover that liability exposure by creating future revenue sources (cash inflows) in that currency. 
If a MNC with $\$ 1$ billion in debt transforms just 10 percent or its debt into a low interest rate currency, and saves 3 percentage points on the interest rate, it will reduce its financing costs by $\$ 3$ million per year.

\section{Limitations to Consider}

The multinational policies recommended to reduce the financing costs of GLOBAL Inc. can distort the profit distribution of the individual units that make up the corporation. Any arrangement by which funds within the corporation are being reallocated to capitalize on the low cost of financing can cause a distortion in profits to the individual subsidiaries. This can limit the degree to which a firm may be able to implement the strategies proposed here. To avoid adverse consequences from such a distortion, a centralized management group should be assigned the power to make decisions on the policies involved. This will avoid any potential infighting between subsidiaries on policies that may help one subsidiary at the expense of another. Policies should be determined with consideration of not any individual subsidiaries, but of the MNC as a whole. To ensure that management at the subsidiary level maintains a congruent objective of contributing to the overall value of the MNC, they should be rewarded according to their contribution to this objective rather than their individual profit level. Some MNCs currently follow this managerial style in order to maximize the welfare of the overall MNC.

A second possible limitation to the strategies proposed here is the existence of related host government laws. For example, a transfer pricing policy desired by the MNC may not be allowed by a particular host government. While this would prevent use of transfer pricing to build net revenues in the low interest rate currency, the alternative strategies proposed here could be implemented instead.

Some host governments may prevent the home currency from being converted into another currency. This would disrupt the plan of borrowing the low interest rate currency and converting it to the currency needed. Such a barrier typically exists only in non-industrialized countries. Thus, the creative financing could still take place within most industrialized countries. Given that the MNC needs to generate future revenues in whatever low interest rate currency it borrows, it would likely consider only the currencies of industrialized countries anyway.

While the potential obstacles identified here are worth considering, they should not prevent a MNC from restructuring its liability composition in order to reduce its cost of capital. None of the obstacles is too large to forego the opportunity to save the company millions of dollars.

\section{Concluding Comments}

MNCs have generally been very willing to consider potential revenuegenerating ideas in foreign markets. They have also been willing to consider a variety of cost-cutting ideas. These ideas have served as the motivation 
for firms to become multinational in the first place. However, there has been a tendency to take financing costs as given, as if the MNC has no control over them. Granted, the MNC does not dictate interest rate levels in various countries. Yet, it does have control over the source from which it obtains its necessary financing. Interest rates in some countries are sometimes seven percentage points (annually) less than where the MNC is currently obtaining its funds. How large must this interest rate differential become for MNCs to realize the potential savings that can be achieved by the creative financing discussed here? It is hoped that this article will help managers recognize that the differential already merits their attention in strategic planning. 